\title{
Study on the Monthly Variation in Hydro biological Condition and Its Relation to Fish Production of a Sewage Fed Bheri System at Suburban Kolkata
}

\author{
Chatterjee NR*, Sahoo D and Chetri C \\ Department of Aquaculture, West Bengal University of Animal and Fishery Sciences, Belgachia, Kolkata-700037, India
}

\begin{abstract}
The concept of resource recovery systems and waste recycling involving the wetlands of Kolkata are gradually loosing interest due to unplanned urban expansion without understanding the ecological, environmental and economic benefit of the century old sewage fed systems. The water quality parameters, noted during the study, exhibited marked seasonal variation and some were indicative of productivity. The BOD was optimum but DOM (Dissolved Organic Matter) was significantly lower. Among the nutrients, the values of phosphorous were higher and the values of all other nutrients found to increase with temperature. Overall production decreased in the successive years. Total plankton production, nitrate-nitrogen, and DOM and BOD showed negative co-relation with total fish production.
\end{abstract}

Keywords: Bheri; Variation; Hydrobiological condition; Production

\section{Introduction}

The world is facing a diverse variety of interrelated problems such as food scarcity, nonrenewable energy source, unemployment and urbanization. The current dilemma occurs because of our strategies for development contravenes the basic philosophy of ecology. The world ecology is increasingly becoming more unstable through an ever dependence on finite resources of fossil fuel, which has been brought sharply into focus by recent hike in the price of crude oil. Food production system in the developing countries, both agriculture and aquaculture, are energy intensive and thus are not considered suitable for developing countries. An alternative strategy, for aquaculture and agriculture development, is dependence on locally available resources of renewable energy and resources. A significant impact could be made through recycling of organic waste and it is suggested that organic waste should be recycled into fish whenever feasible, since fish raised in such a way may be cheapest source of animal product [1].

Sewage can be defined as a cloudy fluid arising out of domestic wastes containing mineral and organic matter either in solution or in suspension or in colloidal or in pseudocolloidal form in a dispersed state. The daily rate of sewage production in India is estimated to be about $100 \mathrm{lt} /$ capita. Thus about 3-4 million $\mathrm{m}^{3}$ of sewage is produced daily in the cities as against a total flow of wastewater of 10 million $\mathrm{m}^{3} /$ day. It is increasingly being recognized that domestic sewage which is rich in nutrient resources (like $\mathrm{N}, \mathrm{P}, \mathrm{K}$ and organic matter) can be suitably utilized for productive purpose [2]. The farmers around kolkata city are using domestic sewage for fish culture almost a century ago and which is widely used to meet the growing demand of fish in this thickly populated Indian city. The system appears to have started long back although large scale use of sewage for fish culture began in 1930s. The area under this unique system of culture peaked at 12000 ha, but in recent years there happens to be steep decline in the area due to increasing urbanization. Currently the area under sewage fed culture system has been reduced to less than 4,000 ha and the people dependent on these wetlands for their livelihood have been seriously affected. These sewage fed fish ponds, which are locally known as "Bheries" are usually large and as big as 40 hector in size, these sewage fed fish ponds are generally shallow and vary from $50 \mathrm{~cm}$ to $150 \mathrm{~cm}$. In general farming here constitutes five distinct phases covering pond preparation, primary fertilization, fish stocking, secondary fertilization and fish harvesting. Currently 148 units of such fisheries are reportedly operating in Eastern Kolkata with the current production of 4-5 ton/ ha./yr. These sewage fed Bheries around suburban kolkata are well managed by different co-operatives. The sewage fed Bheri under present study is managed by and occupy an area about 75 ha the average depth is around $1 \mathrm{mt}$. Management by co-operative started in mid 1980s with the support of Govt. The annual transaction of this society are large is magnitude with financial transaction amounting to move than Rs. 13 million. There exist also an integration of pig and duck. This sewage fed system is subjected to stress and strain in the form of less availability of nutrient as the good quality of raw sewage are not coming to the systems. The scientific investigation of this vast water body was undertaken with the following objectives.

$>$ To determine seasonal variation in the hydrobiological condition of this 'Bheri' system.

$>$ To evaluate the production performance of fish per hector water body.

> To correlate the fish production/month with consequent variation in hydro biological parameters.

$>$ To investigate the importance and effectiveness of this water body in the treatment of Kolkata city sewage.

\section{Materials and Methods}

The present study was carried out to investigate the seasonal

*Corresponding author: Chatterjee NR, Department of Aquaculture, West Benga University of Animal and Fishery Sciences, Belgachia, Kolkata-700037, India, Tel: +55 14 38800470; E-mail: nrchatterjee40@gmail.com

Received August 12, 2014; Accepted September 27, 2014; Published October 01, 2014

Citation: Chatterjee NR, Sahoo D, Chetri C (2014) Study on the Monthly Variation in Hydro biological Condition and Its Relation to Fish Production of a Sewage Fed Bheri System at Suburban Kolkata. J Aquac Res Development 5: 279. doi:10.4172/2155-9546.1000279

Copyright: (c) 2014 Chatterjee NR, et al. This is an open-access article distributed under the terms of the Creative Commons Attribution License, which permits unrestricted use, distribution, and reproduction in any medium, provided the original author and source are credited. 
variability of water and soil quality status and fisheries potentialities of Bheri No. 4 receiving sewage effluent at weekly interval. This sewage fed Bheri situated at suburban Kolkata, which is under East Kolkata wetland area. The detailed survey on Physico-chemical status of water, sediment quality and biological status was carried out for a period of 6 months. Standard method of APHA [3] was followed for this purpose. In order to study the water body, three sampling sites were selected covering entire stretch of the Bheri. Fortnightly collection of water samples were done for six month period from January 2006 to June 2006. Planktons and soil samples were collected once in a month. All the experiments were conducted between $10.00 \mathrm{am}$ to $1.00 \mathrm{pm}$. Annual fish landing data were taken from the official records of the Co-Operative.

\section{Field studies}

Collection of samples for soil/water quality and plankton analysis: For water quality estimation, water samples were collected from three sampling sites without disturbing the bottom sediments. Soon after the collection, temperature was recorded using a mercury thermometer to the nearest $0.10^{\circ} \mathrm{C}$. Samples were fixed following standard method as in APHA. During collection of water samples, cautions were taken so as to prevent air bubbling, which might influence water parameters such as dissolve oxygen, free carbon-di-oxide etc. Soil samples and plankton are also collected following standards methods.

Pond preparation and Management pattern: In general pond management includes five phases such as pond preparation, primary fertilization, stocking, secondary fertilization and fish harvesting.

Pond preparation: Generally after every 5-6 years ponds are drained, dried and silt are removed from the topsoil of pond bottom, the bottom is tilled, lime applied on the top surface and dikes are renovated. The pond preparation generally undertaken during winter months.

Primary fertilization: Sewage is drawn from central canal into the pond and allowed to stabilize for 15-20 days. The photosynthetic activities in the pond is the basis of biological purification of the sewage. Once the water turns complete green, fish are stocked.

Fish stocking: Large size fingerlings are stocked after every 3 months in a year as harvesting continues throughout the year.

Periodic fertilization: Following fertilization, sewage is fed to ponds @ 5\% of the total volume of water at interval throughout the culture period. Continuous inflow and outflow is maintained (Figure 1).

Dike protection: Dyke is protected by water hyacinth which provide shelter to the fish and remove heavy metals.

Fisheries: Fish catches in every effort were observed during the entire investigation period. Percentage contribution of different group of species were computed and prevalence of diseases was also carefully noted.

\section{Laboratory studies}

Physico-chemical analysis of water: Different physico-chemical parameters of water were estimated by following standard methods as in APHA 1998 (Figure 2).

Estimation of Soil parameters: $\mathrm{pH}$ and organic carbon was measured by following standard methods (APHA, 1998).

\section{Statistical analysis}

The data obtained in respect of different parameters were statistically

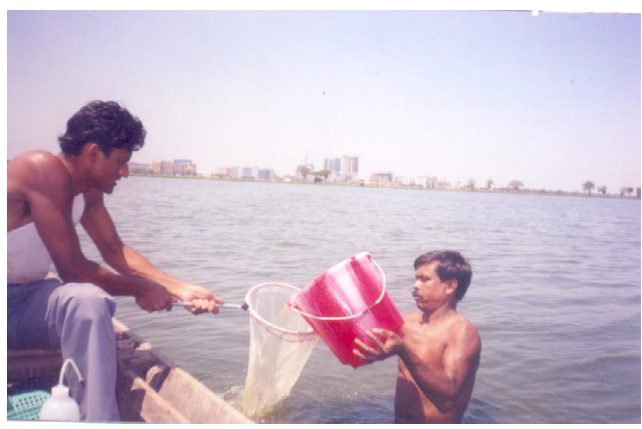

Figure 1: Plankton collection at one of the sampling site.

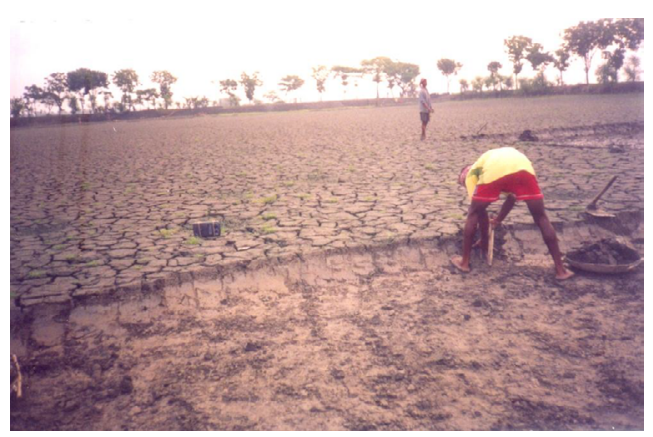

Figure 2: One ft. deep pond mud being cut and stacked on the bank.

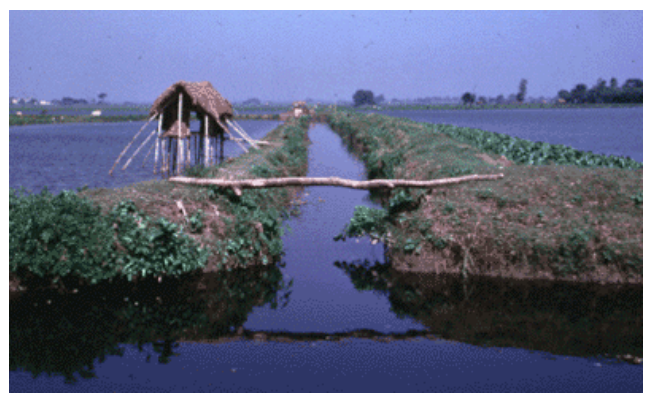

Figure 3: Central sewage canal fed to different Bheris.

analyzed following Analysis of variance to derive the significant difference between the sampling sites. Correlation coefficient $(r)$ values between physico chemical parameters of water and phytoplankton were also worked out.

\section{Results}

\section{Physico-chemical properties of the Bheri system}

Hydrobiology: The seasonal variation in physico-chemical parameters of the Bheri system affects the productivity chain and as a result of this the entire aquatic productivity equilibrium is disturbed (Figure 3). Depending on the incoming waste materials into the system, the hydrobiological properties varied. Besides, the high percentage of chemical waste results in substantial variation in physico chemical properties (Figure 4). With this understanding, the hydro biological characteristics of the Bheri were fortnightly estimated.

Temperature: Temperature varied from a minimum of $21.3^{\circ} \mathrm{C}$ 


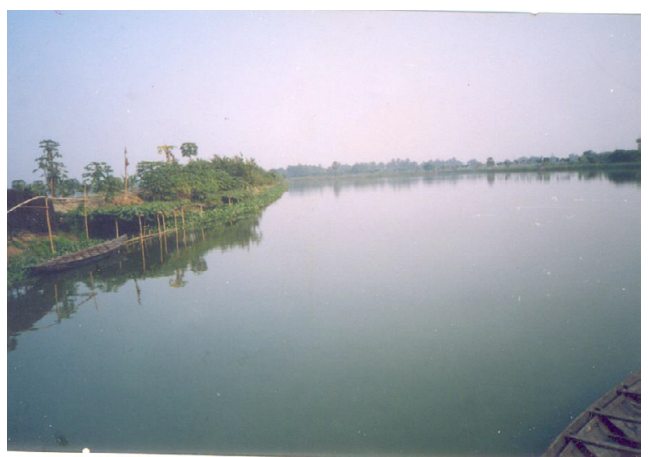

Figure 4: Periphery of this Bheri covered with Eichhornia plant to protect from windaction.

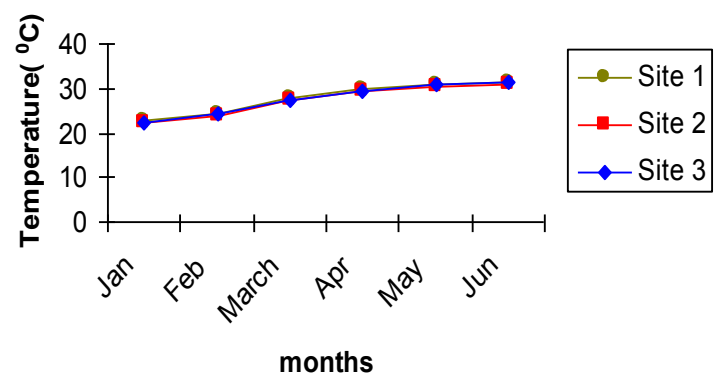

Figure 5: Trend in variation of temperature $\left({ }^{\circ} \mathrm{C}\right)$ at three sampling sites.

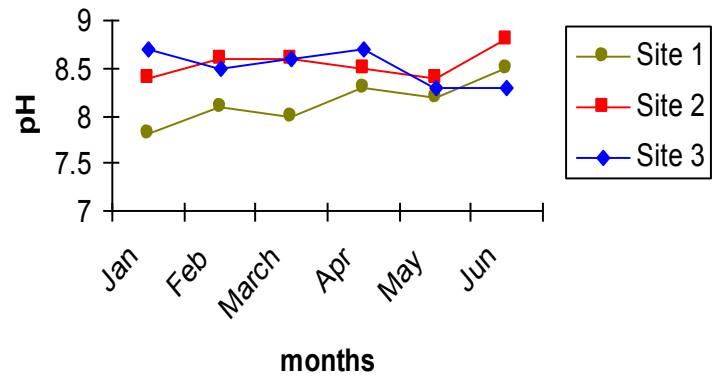

Figure 6: Trend in variation of $\mathrm{pH}$ at three sampling sites.

(January, Site 2) to a maximum of $32.3^{\circ} \mathrm{C}$ (June, Site 3) (Figure 5), means an increasing trend from January to June.

pH: Normally the pH ranged between the minimum values of 7.5 (January, Site 1) to the maximum value of 8.9 (June, Site 3) (Figure 6). All three sites showed highly alkaline $\mathrm{pH}$ but Site 2 showed slightly higher $\mathrm{pH}$ value.

Dissolved Oxygen: All three sampling site showed marked variation in dissolved oxygen content (Figure 7) and ranged from a minimum of $1.50 \mathrm{mg} / \mathrm{lt}$ (May, Site 2) to a maximum of $4.04 \mathrm{mg} / \mathrm{lt}$ (February, Site 3).

Free Carbon dioxide: Figure 8 indicate that, the $\mathrm{CO}_{2}$ content was nil except in June with a minimum of $1.64 \mathrm{mg} / \mathrm{lt}$ (Site 3, June) and maximum of $2.20 \mathrm{mg} / \mathrm{lt}$ respectively.

Biological Oxygen Demand (BOD): As indicated in Figure 9 the
BOD value ranged between $20.76 \mathrm{mg} / \mathrm{lt}$ (January, site 1 ) to $10.70 \mathrm{mg} / \mathrm{lt}$ (site 3 ) showed higher value.

Total alkalinity: Total Alkalinity fluctuated widely at three sampling sites (Figure 10) and ranged from $208.7 \mathrm{mg} / \mathrm{lt}$ (January, Site 3) to $315.3 \mathrm{mg} / \mathrm{lt}$. Site 1 showed higher value due as the raw sewage enter through it.

Ammonia-Nitrogen: Ammonia-Nitrogen ranged from $0.740 \mathrm{ppm}$ (January, Site 3) to the maximum of $1.402 \mathrm{ppm}$ (June, site 1) (Figure 11). Higher value at site 1 due to entry of raw sewage.

Nitrate-Nitrogen: Nitrate -nitrogen content varied at different site (Figure 12). Site 3 showed higher values than the other sites and ranged between $0.120 \mathrm{ppm}$ (June, site 1) to $0.282 \mathrm{ppm}$ (January, site 3).

Phosphate-Phosphorus: The fortnightly variations was noticed at three sites (Figure 13) with a maximum of $1.826 \mathrm{mg} / \mathrm{lt}$ (March, Site 1)

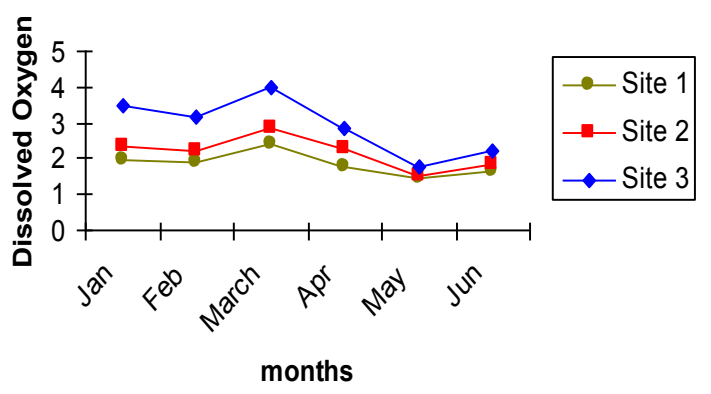

Figure 7: Trend in variation of Dissolve Oxygen $(\mathrm{mg} / \mathrm{lt})$ at three sampling sites.

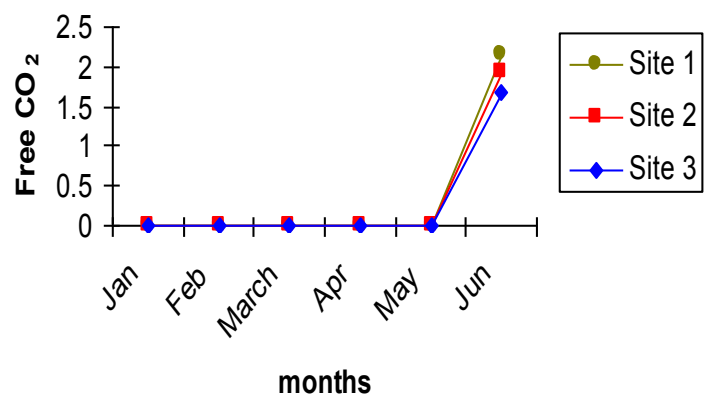

Figure 8: Trend in variation of free Carbon di Oxide (mg/lt) at three sampling sites.

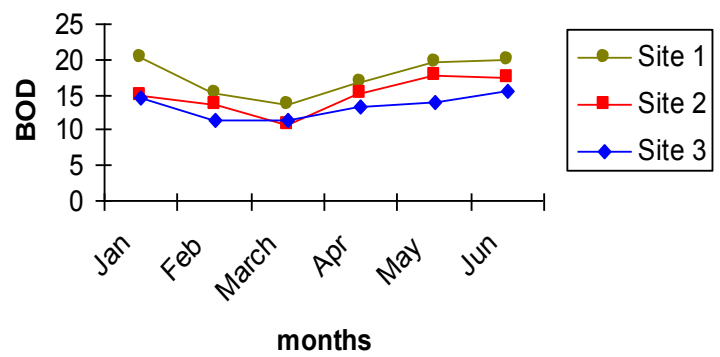

Figure 9: Trend in variation of Biological Oxygen Demand (mg/lt) at threesampling sites. 


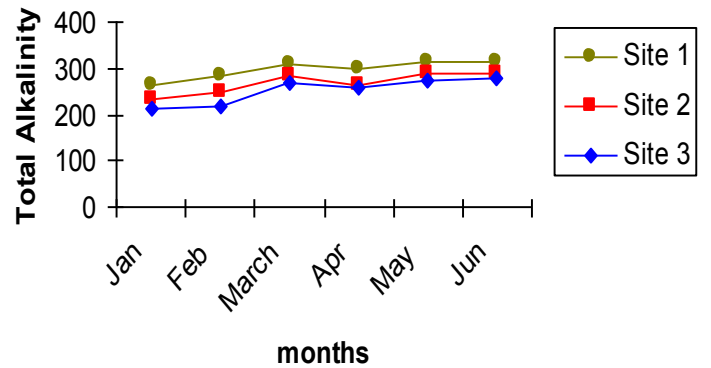

Figure 10: Trend in variation of Total Alkalinity $(\mathrm{mg} / \mathrm{lt})$ at three sampling sites.

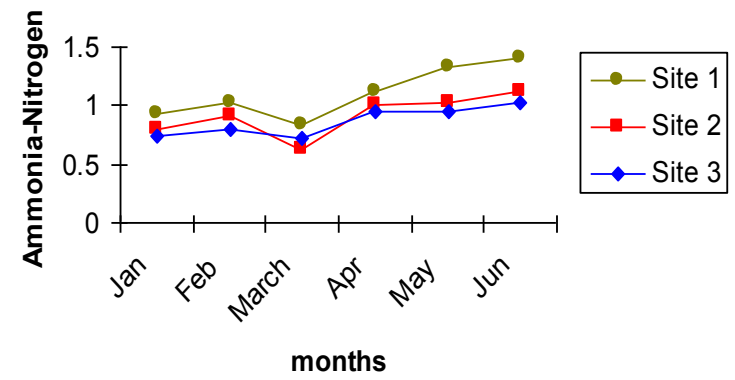

Figure 11: Trend in variation of Ammonia-Nitrogen (mg/lt) at three sampling sites.

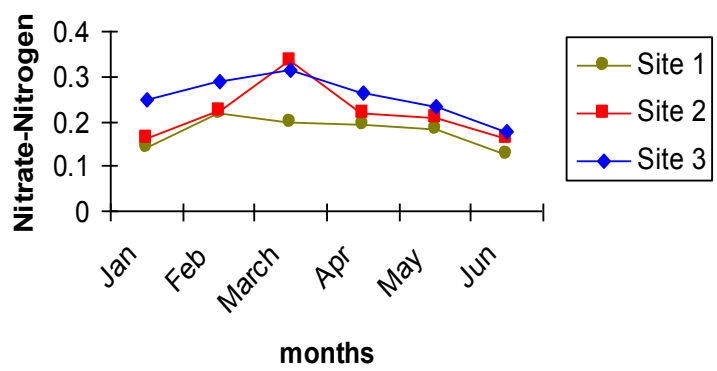

Figure 12: Trend in variation of Nitrate-Nitrogen $(\mathrm{mg} / \mathrm{lt})$ at three sampling sites.

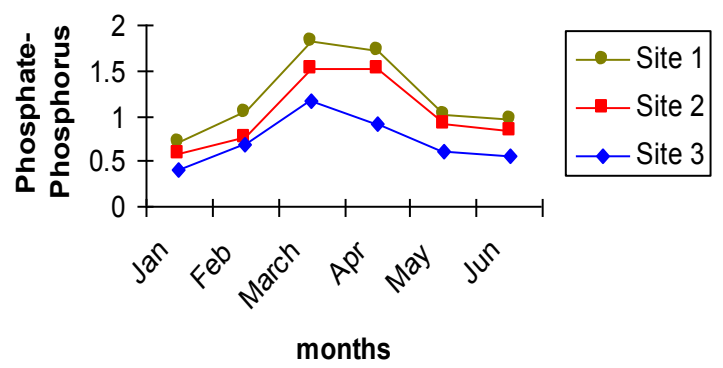

Figure 13: Trend in variation of Phosphate-Phosphorus (mg/lt) at three sampling sites. to a minimum of $0.401 \mathrm{mg} / \mathrm{lt}$ (January, Site 3). The overall trend was moreover same.

Dissolved organic matter: Dissolved organic matter showed a lower range and fluctuates between $3.542 \mathrm{mg} / \mathrm{lt}$ (March, site 3) to 6.416 $\mathrm{mg} / \mathrm{lt}$ (may, site 1). Organic matter content was rich in site 1 than the other two sites (Figure 14) as usual.

\section{Soil}

pH: Varied between 6.9 (March, site 2) to 7.3 (May, site 2) values at 3 sites were comparable (Figure 15).

Organic carbon: The range at three sites were between $1.32 \%$ (January, site 3 ) to $2.41 \%$ (May, site 1). Steady increase in organic carbon content (\%) was noticed at all the sites from January to June (Figure 16).

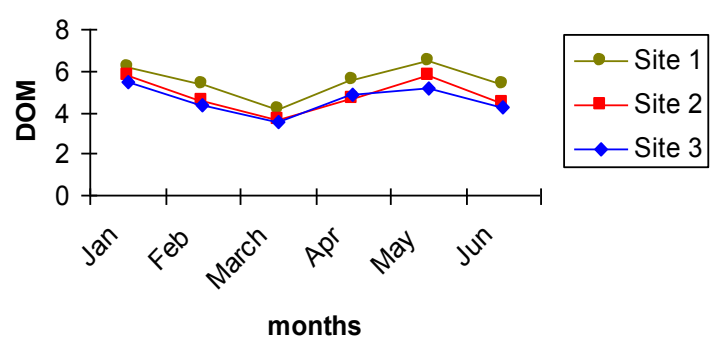

Figure 14: Trend in variation of Dissolved Organic Matter (mg/lt) at three sampling sites.

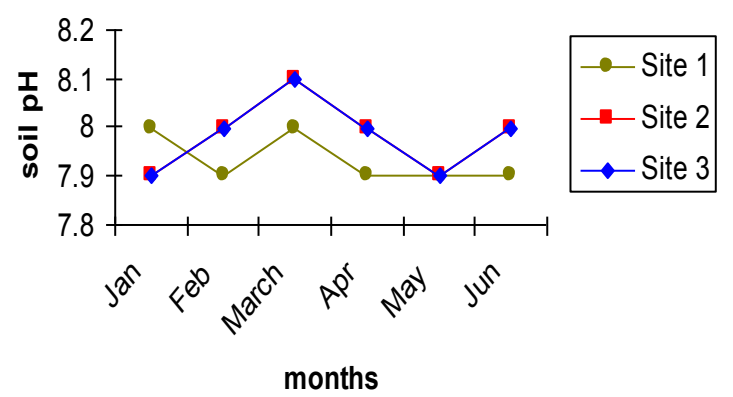

Figure 15: Trend in variation of soil $\mathrm{pH}$ at three sampling sites.

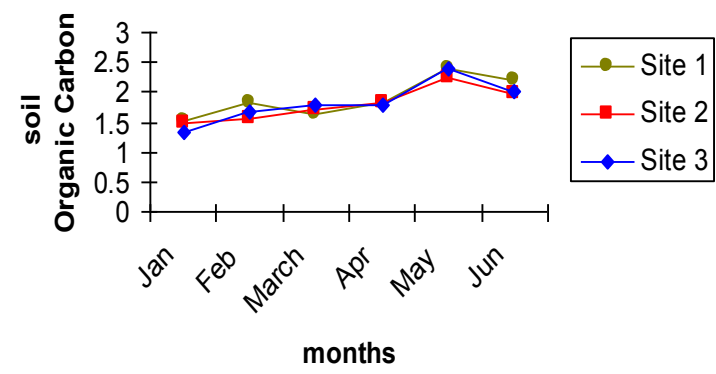

Figure 16: Trend in variation of Organic Carbon (\%) of soil at threesampling sites. 
Citation: Chatterjee NR, Sahoo D, Chetri C (2014) Study on the Monthly Variation in Hydro biological Condition and Its Relation to Fish Production of a Sewage Fed Bheri System at Suburban Kolkata. J Aquac Res Development 5: 279. doi:10.4172/2155-9546.1000279

Page 5 of 8

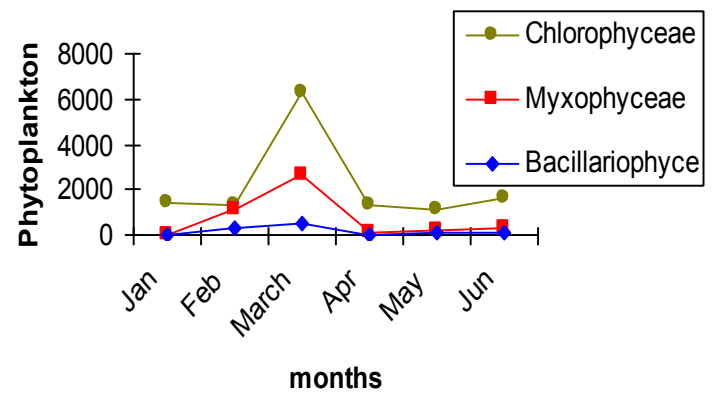

Figure 17: Trend in variation of phytoplankton population (nos. /lt).

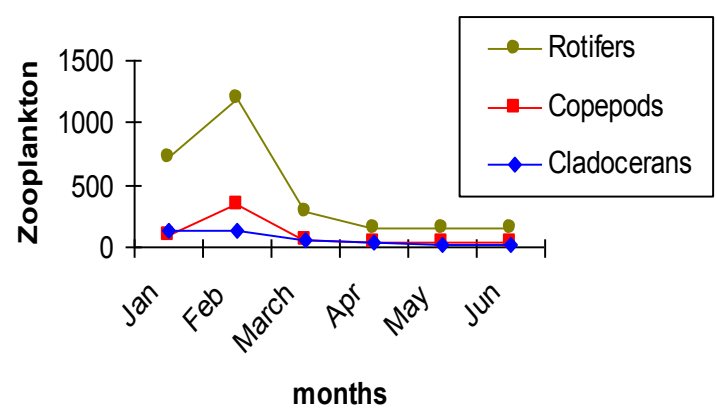

Figure 18: Trend in variation of Zooplankton population (nos. /lt).

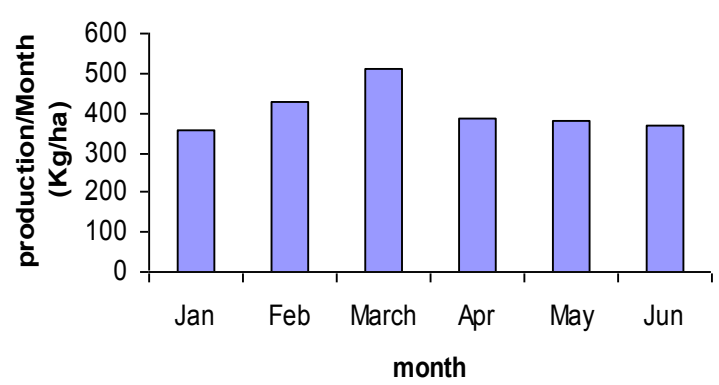

Figure 19: Result of monthly carp production at sewage fed Bheri No. 4.

\section{Planktons}

As the sewage fed system carry high nutrient load, so it serves as a ready source for plankton growth. Dense phytoplankton bloom noticed in some places.

Phytoplankton: The total phytoplankton count varied from a minimum of 800 no /lt (May) to a maximum of 9434 no /lt (March) (Figure 17). The major group was chlorophyceae, Myxophyceae and Bacillariophyceae showing variable intensity with time. Chlorophyceae dominates the other two groups are represented by Coelastrum, Pediastrum, Spirogyra, Oscillatoria and Spirulina. The next dominating group was Myxophyceae while Bacillariophyceae represented by few Navicula and Synedra.

Zooplanktons: The major group represented by Rotifers, Copepods and Cladocerans (Figure 18). Rotifers dominated the other two groups and represented by Brachionus, Keratella and Cyclops while copepod represented by Diaptomum. Cladocerans mainly dominated by Moina and Daphnia spp. Rotifer population was maximum in February (1203 nos/lt) and minimum in June (157 nos/lt). Rotifer population dominated in Feb (1203 nos/lt) and minimum during June (157 nos/ lt). Minimum count of Copepods was obtained in the month of May (30 nos/lt) and maximum in the month of February (334 nos/lt). Cladocerans showed its peak in the month of February (134 nos./lt) and minimum in the month of June (22 nos/lt).

\section{Fish stocking and production of the Bheri}

Both Indian and exotic carps are stocked in Bheris, with a preference over Indian carps due to their herbivorous feeding behavior and high growth rate and includes Catla (Catla catla), Rohu (Labeo rohita), Mrigal (Cirrhinus mrigala) and Bata (Labeo bata) but mrigal outnumber other carps. Generally fingerlings and stocked to reduce mortality rate [4-7] (Figure 19). The culture of Tilapia (Oreochromis nilotica and $O$. mossambicus) is getting popularity and constitute about $5-10 \%$ of the stock. Fingerlings are stocked at three months interval.

\section{Disease occurrence}

Only ulcers (Epizootic Ulcerative Syndrome, EUS) were found to a lesser extent on the body of mrigal and on silver carps in winter months. Carp lice (Argulus) and parasitic infection Lernea (anchor worm) were recorded on mrigal and catla in the month of February (Figure 20). Occurrence of other diseases were not noticed.

\section{Fish harvesting and marketing}

Harvesting is done every day in early morning in between 4 am to 6 am at different Live fish marketing is becoming more popular, and is considered a kind of value addition to fetch more price (Tables 1 and 2). The captured fish are stocked in a depuration pond for varying length of time. Depurated fish are marketed alive location by drag net.

\section{Statistical Analysis}

The data obtained were statistically analyzed by employing analysis of variance (ANOVA one-way) and Pearson's correlation method. The summary of these ANOVA is presented in appendix 1.

Relationship of water and sediment quality parameters with fish production (for site 1,2 and 3) were done using method of Backward

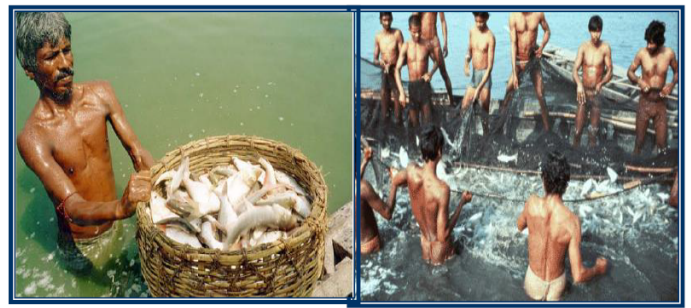

Figure 20: Carps harvested from the sewage fed Bheri.

\begin{tabular}{|c|c|}
\hline $\begin{array}{c}\text { Indian major Carp; Minor carps; } \\
\text { Exotic carps }\end{array}$ & $\begin{array}{r}12000 \text { kg fingerlings at a time each } \\
\text { three months interval }\end{array}$ \\
\hline Other fishes & Natural entry \\
\hline \multicolumn{2}{|c|}{ Table 1: Rate of Stocking. }
\end{tabular}

\begin{tabular}{|c|c|}
\hline Year & Production (metric ton) \\
\hline $2001-2002$ & 547.50 \\
\hline $2002-2003$ & 412.26 \\
\hline $2003-2004$ & 403.80 \\
\hline $2004-2005$ & 358.20 \\
\hline
\end{tabular}

Table 2: Harvesting of fishes in the last four years. 
elimination technique of Multiple regression because of less number of sample size with probability of $\mathrm{F}$ to enter as 0.05 and $\mathrm{F}$ to removal as 0.10 .

(Following equations has been extracted taking least predictors to explain the growth):

1) Production Site- $1=318.62-10.23^{*} \mathrm{CO}_{2}+40.68^{\star *} \mathrm{PO} 4-\mathrm{P}+0.25^{\star *}$ Bacilariophyceae R2 $=0.99$, adj. R2 $=0.99$, S.E. of Estimated $=3.46$

2) Production Site- $2=349.80-1.32$ water temp. $-8.48^{*} \mathrm{CO}_{2}$ $+51.42^{*} \mathrm{PO} 4-\mathrm{P}+0.26^{* *}$ Bacilariophyceae $\mathrm{R} 2=0.99$, adj. R2=0.99, S.E. of Estimated $=0.52$

3) Production Site- $3=315.48-11.54 \mathrm{CO}_{2}+79.15^{*} \mathrm{PO} 4-\mathrm{P}+0.22^{\star *}$ Bacilariophyceae R2 $=0.99$, adj. R2 $=0.99$, S.E. of Estimated $=4.27$

In the above equations it has been assumed that production is time independent but actually it should be time related or autoregressive over the period of observations. Thus in the following equations autoregressive model along with predictor variables as selected by previous equations following Melard's algorithm for estimation for all sites and the ultimate equations were made.

1) Production Site- $1(n)=318.95-0.85$ production site $1(n-1)$ $-11.21 \mathrm{CO}_{2}+39.91^{\star} \mathrm{PO} 4-\mathrm{P}+0.25^{\star}$ Bacilariophyceae Adj. S.S=13.16, Marquardt const. $=1.00-\mathrm{E} 8=1.00 \times 10-8$, No. of iterations $=6$

\#Note: PO4-P (Phosphate phosphorus) followed by bacillariophyceae have enhance the production but $\mathrm{CO}_{2}$ have suppressed the production at site 1 .

2) Production Site $-2(n)=323.53-0.85$ production site $2(n-1)$ $-14.93 \mathrm{CO}_{2}+40.86 \mathrm{PO} 4-\mathrm{P}+0.27^{*}$ Bacilariophyceae Adj. S.S. $=27.07$, Marquardt const. $=0.10$, No. of iterations $=7$

\#Note: Bacilariophyceae have enhanced the production in site 2.

3) Production Site-3 $(n)=316.24-0.84$ production site $3(n-1)$ $-13.53 \mathrm{CO}_{2}+76.75 \mathrm{PO} 4-\mathrm{P}+0.23^{*}$ Bacilariophyceae Adj. S.S. $=22.14$ Marquardt const. $=1.00-\mathrm{E} 7=1.00 \times 10-7$, No. of iterations $=5$

\#Note: Bacilariophyceae have enhanced the production in site 3.

$\left(^{*}\right)=$ Result is Significant at 0.05 levels

$\left({ }^{* *}\right)=$ Result is Significant at 0.01 levels

\section{Discussion}

As we know production in bheris is intimately related to physicochemical properties at soil-water interface and sewage quality. During this study emphasis was given for characterization of water and sediment quality and assessment of suitable ecosystem, for optimum fish growth. The study was conducted covering leading Bheris of North Kolkata.

\section{Hydrography}

Temperature: The degree and annual variation in temperature of water body have a great bearing upon its productivity in general. Any fluctuation in water temperature affects other environmental parameters. Our data confirm that temperature positively co-related with the total alkalinity (0.940) but no significant co-relation existed between temperature and monthly fish production.

$\mathbf{p H}$ : The alkaline $\mathrm{pH}$ range in spite of considerable amount of organic load may be attributed to high rate of photosynthetic activity in the pond water and also to the prevalence of large amount of water- soluble bases. $\mathrm{pH}$ is considered favorable for good yield of fish. Higher $\mathrm{pH}$ value during summer month (March to May) may be due to the concentration of sewage resulted from high degree of evaporation. During rest of the season $\mathrm{pH}$ value was average. Presence of substantial amount of organic matter, increase $\mathrm{CO}_{2}$ production, which in turn lowers the $\mathrm{pH}$ value. Oswald [8] and Seenayya [9] also reported higher $\mathrm{pH}$ value in sewage water. No significant co-relation was observed between $\mathrm{pH}$ and monthly fish yield (Appendix-I).

Dissolved Oxygen: Dissolved oxygen content is important for direct need affects the solubility and availability of many nutrients and therefore the productivity of aquatic ecosystem [10]. In the present investigation there was an erratic fluctuation of dissolved oxygen content in all the ponds throughout the study period. DO concentration around $5 \mathrm{ppm}$ was found to be favorable for fish growth [11-13]. In our study dissolved oxygen exhibited a direct relationship (0.820) with total phytoplankton production and strong negative co-relation (-0.925) with ammonia nitrogen $\left(\mathrm{NH}_{3}-\mathrm{N}\right)$.

Carbon di Oxide: The value of $\mathrm{CO}_{2}$ fluctuate widely due to its capacity to combine with different cataions $\left(\mathrm{Ca}^{++}, \mathrm{Na}^{+}, \mathrm{K}^{+}\right)$and other elements. During the study dissolved free $\mathrm{CO}_{2}$ concentration was found nil except in the month of June ( $1.92 \mathrm{ppm}$ to $2.21 \mathrm{ppm}$ ). The absence of free $\mathrm{CO}_{2}$ might be due to the presence of high phytoplankton bloom. No significant co-relation between the presence of carbon dioxide and fish production was found. As indicated Goel and Trivedi the increase in organic matter results in high biological and chemical demand, with consequent decrease in the dissolved oxygen levels and increase in free carbon-di-oxide level.

Biochemical Oxygen Demand: Generally sewage fed Bheries exhibits higher values of Biochemical oxygen demand but we did not notice any definite change in BOD throughout the investigation although sitewise there was the marked variations in BOD level. In present investigation the $\mathrm{BOD}$ ranged from a minimum value of $11.52 \mathrm{ppm}$ (February) to maximum of $20.3 \mathrm{ppm}$ (June). In the present investigation the BOD values were found within the desired range Biochemical oxygen demand showed highly significant negative co-relation with Nitrate Nitrogen (0.944) and total phytoplankton production (-0.844) respectively.

Total alkalinity: Total alkalinity is related to the productivity of waterbody. In the present investigation fluctuation in total alkalinity at different centre was not significant. The average value ranged from 210-315.3 ppm. In all the sites peak was observed in June and minimum in January. Fish ponds having alkalinity of $50 \mathrm{mg} / \mathrm{lt}$ are considered productive $[11,12]$. High total alkalinity value may lead to the liberation of $\mathrm{CO}_{2}$ following the process of decomposition of bottom deposit. The importance of alkalinity in view of its relationship with available $\mathrm{CO}_{2}$ for photosynthesis was emphasized by wallen [14]. A highly productive water should have total alkalinity more than $100 \mathrm{ppm}$ [15]. Since all the sites showed a total alkalinity value above $100 \mathrm{mg} / \mathrm{lt}$, it is not likely to be a limiting factor for the productivity of a pond, but on the basis of total alkalinity value the existing farm may be classified as productive. No significant co-relation was noted between total alkalinity and fish production. But total alkalinity showed highly positive correlation with temperature.

Ammonia-Nitrogen $\left(\mathrm{NH}_{4}-\mathrm{N}\right)$ : Raw sewage is the source of higher concentration of ammonia -nitrogen. Although the ammonia is a major excretory product of aquatic animals but this nitrogen source is quantitatively minor in comparison to that generated by microbial decomposition. It is present in the aquatic system mainly 
as dissociated ionic $\mathrm{NH}_{4}^{+}$. In all the sites a narrow range of ammonia nitrogen from 0.723 to 1.402 was noticed. Site 1 showed higher range of ammonia nitrogen as it serves as entry of raw sewage. Relative amount of ammonia nitrogen is higher than the nitrate nitrogen due to low oxygen concentration. At higher $\mathrm{pH}$ and temperature ammonia is toxic to fish [12]. In the afternoon period nitrification of ammonia to nitrate enhances to a considerable level [16]. Generally sewage fed ponds exhibit high level of ammonia. No adverse effect however, on the fish due to high concentration of ammonia was observed [6,17]. Our study confirms the earlier one. No co-relation between ammonia nitrogen (NH4-N) with monthly fish production was found to exist but NH4-N showed significant negative co relation $(-0.925)$ with dissolved oxygen.

Nitrate-Nitrogen $\left(\mathrm{NO}_{3}-\mathbf{N}\right)$ : Nitrate- Nitrogen is an important water parameters and influence productivity of aquatic system. Welch opined that nitrate in natural water exists in a continuous changing state due to the relation of nitrate with nitrifying bacteria and demand by nitrate consuming organisms such as phytoplankton and higher aquatic plants. Nitrate-Nitrogen value varied considerably during the study period. Generally higher values observed during summer month and ranged from $0.125-0.336 \mathrm{ppm}$ with a peak value in April, may be due to mineralization process at higher temperature. Saha et al. [18] reported a nitrate value from 0.08-1.80 ppm at Kulia beel during 198182. A similar trend was observed by Bhoumik [19] in beels and bours of West Bengal. A positive and highly significant co-relation (0.899) was found between nitrate-nitrogen content and monthly fish production. Nitrate nitrogen also showed significant direct relation (-0.944) with biochemical oxygen demand.

Phosphate-Phosphorus ( $\left.\mathbf{P O}_{4}-\mathbf{P}\right)$ : Phosphorus mainly occurs in the form of orthophosphates and is the most critical factor in maintaining pond productivity [20]. Phosphate value did not show any seasonal variation. A more favorable growth response of plankton population was observed at the time of higher concentration of phosphates in pond water. Higher value of phosphorus observed during MarchApril month (1.82-1.73 ppm) and minimum value was observed during January $(0.423 \mathrm{ppm})$. A productive pond passes a phosphorus concentration of 0.02-0.05 ppm [20]. Significant co relation also could not found between phosphorus and other parameters. Direct influence of available phosphorus with productivity was established and confirms the findings of Ghosh $[2,20]$.

Dissolved Organic Matter (DOM): The dissolved organic matter of the Bheri varied between 3.531-6.512 ppm with a higher value recorded during summer months. Dissolved Organic Matter content showed a significant indirect relation $(-0.822)$ with fish production. No such relations were found with other parameters.

\section{Soil}

pH: Soil $\mathrm{pH}$ at neutral range ( $\mathrm{pH} 6.5$ to 7.5 ) is suitable for fish culture. $\mathrm{PH}$ value fluctuates depending on soil. In the present study the soil $\mathrm{pH}$ ranged between 6.9-7.3.

Organic carbon: Organic carbon was found very high in the fish pond and ranged between $1.32 \%$ to $2.41 \%$. Ghosh et al. [20,21] found a similar trend of organic carbon range. Present study conforms the above findings of earlier study. Muds are water logged and often deficient in dissolve oxygen. Low concentration of dissolve oxygen prevents efficient utilization of organic matter by bacteria. In the present case accumulation of organic carbon may be attributed to heavy load of oxygen deficient mud.

\section{Plankton}

In sewage fed fishpond, plankton is the principle natural food component for the fishes and is directly linked with fish production. The data derived from the present investigation represent a distinct variations in composition of zooplankton and phytoplankton in different months. The maximum recorded in February- march (9834 nos. /lt) and minimum in May (1011 nos/lt) indicating a bimodal distribution of planktons in the sewage fed pond. Similar pattern of plankton distribution was reported by [22].

Phytoplankton: Phytoplanktons are primary producer and form the basis of an autotrophic food chain. In all the sewage fed fishponds phytoplanktons showed high concentration and are considered an important biotic component of an aquatic system. During present investigation phytoplankton population varied between 800 nos./lt (May) to 9432 nos./lt (March) in all the sites. The rise in phosphate concentration may be attributed to themineralization of nutrients which causes enhancement of phytoplankton abundance. Seven species of phytoplanktons identified belongs to three groups of algae such as Chlorophyceae, Myxophyceae and Bacillariophyceae. Among the Chlorophyceae the species were Coelastrum, Pediastrum and Spirogyra. Myxophyceae represented by Oscillatoria, Spirulina and Bacillariophyceae group was represented by Navicula and Synedra. Based on numbers the groups were ordered as of Chlorophyceae $>$ Myxophyceae >Bacillariophyceae. In sewage irrigated pond, the nutrients rich effluent enhance the production of phytoplankton as also secondary and tertiary food organisms [20,23,24]. Ghosh et al. [20] while working on hydrobiological condition of sewage fed pond observed similar pattern of phytoplankton concentration. The dominating role of Chlorophyceae in sewage treatment ponds are also reported by $[22,25]$. Colder months are congenial for occurrence of phytoplanktons according to findings. This view confirms with findings of Saha [26].

Zooplankton: The importance of zooplankton in the eutrophication of freshwater ecosystem have been emphasized by many investigators [27]. The seasonal variation of zooplankton in the Bheri was similar to that of phytoplanktons and exhibited its peak in February month (1671 nos./lt) and minimum in the month May (211 nos/lt). The zooplanktons were represented by Rotifers, Cladocerans and Copepods.

Rotifers were dominating among all the Zooplanktons. It was represented by Brachionus and Keratella. Cladocerans were represented by Cyclops and Diaptomus. Compared to phytoplanktons the zooplankton density was lower. The seasonal occurrence and species composition in plankton production is directly or indirectly influenced by physico-chemical factors of water. In the present study plankton density showed highly significant relationship ( $1 \%$ level) with fish production, dissolved oxygen (5\% level) and indirect relation with biochemical oxygen demand ( $5 \%$ level). Vittal Rao reported that BOD of sewage water has significant influence on algal succession, which also favors this investigation.

\section{Fish production}

Waste or sewage fertilized ponds produce high yield because of high abundance of natural food produced in wastes [24]. The overall production of this Bheris was $4800 \mathrm{~kg} / \mathrm{ha} / \mathrm{yr}$. Monthly fish production was documented from cooperative record book. From the year 200102 there is constant decrease in fish production due to unavailability of good quality of sewage. High rate of siltation also found to reduce fish production. 
Citation: Chatterjee NR, Sahoo D, Chetri C (2014) Study on the Monthly Variation in Hydro biological Condition and Its Relation to Fish Production of a Sewage Fed Bheri System at Suburban Kolkata. J Aquac Res Development 5: 279. doi:10.4172/2155-9546.1000279

Page 8 of 8

Sreenivasan recorded fish production ranging from 1000-5486 $\mathrm{kg} / \mathrm{ha}$ from Chennai city sewage fed ponds. Ghosh [22] observed the production of $5402-8619 \mathrm{~kg} / \mathrm{ha}$ when opted for composite fish farming of Indian and exotic carps in sewage irrigated fishpond. Vass, mentioned the use of effluent from domestic septic tanks from Java, and reported that the yield of fish was $4000 \mathrm{~kg} / \mathrm{ha} / \mathrm{yr}$ without any supplementary feed. Saha [26] estimated annual fish production of 2.2 ton/ha from sewage fed fisheries of West Bengal. Schaperclaus [27] reported that the fish crop attributed to sewage ranged from 165$1037 \mathrm{~kg} / \mathrm{ha} / \mathrm{yr}$ from Berlin, Germany. A comparable production were observed in these Bheris [28].

\section{References}

1. Wohlfarth G (1978) Utilization of manure for fish farming. Proceeding of the Conference of on Fishfarming and Wastes, London.

2. Manna NK, Banerjee S, Bhoumik ML (2001) Evaluation of production performance of carp in a lentic freshwater water sewage-fed polyculture pond. Indian J Fish 48: 375-381.

3. American Public Health Association (1998) American Water Works Association and Water Pollution control Federation. Standard method for the examination of water and waste water. (20 th edtn), Am Publ HIth Assoc, Washington, USA.

4. Ghosh D, Sen S (1987) Ecological History of Calcutta's Wetland Conservation Environ Conserv. 14: 219-226.

5. Krishnamurthi KP (1988) Present status of sewage fed fisheries in Maharastra in Wastewater-fed Aquaculture.

6. Prabhavalthy G, Arun GJ (1988) Fish culture in sewage fed ponds of Tamilnadu.

7. Jhingran AG, Ghosh A (1988) Aquaculture as a potential system of sewage disposal a case study. J Inland Fish Soc. India 20: 1-8.

8. Oswald WJ (1960) Light conversion efficiency of algal growth in sewage. J San Eng Div. Am Soc Civil Engr. 86: 71

9. Seenayya G (1971) Ecological studies in the plankton for certain freshwate ponds of Hydrabad, India I Physico-chemical complexes. Hydrobiologia 37: 7-31.

10. Wetzel RG (1983) Limnology. Saunders College Publishing, USA

11. Banerjee SM (1967) Water quality and soil condition of fish ponds in some states of India in relation to fish production. Indian J Fish 14: 115-144.
12. Boyd CE (1982) Water quality management for pond fish culture. Elsevier scientific publishing company, Amsterdam, Kingdom of the Netherlands.

13. Ellis MM (1937) Detection and measurement of stream pollution. US. Bull 58 365-437.

14. Wallen IE (1955) Some limnological considerations in the productivity of Oklahoma farm ponds. J Wildlife Mgmt 19: 450-462.

15. Alikunhi KH (1957) Fish culture in India. Fm. Bull. Indian Coun Agri Res 20 144.

16. Chow T (1958) A study of water quality in the fish ponds of Hong Kong University. Fish J 2: 7-2.

17. Sreenivasan A, Muthuswamy S (1979) Fish culture possibilities in sewage treated ponds of Madrash. J Fish 8: 140-142.

18. Saha SB, Bhagat MJ, Pathak V (1990) Ecological changes and its impact on fish yield of Kulia beel in Ganga basin. J Inland Fish Soc India 22: 7-11.

19. Manna NK, Banerjee SM, Bhoumik ML (1998) Live fish production through waste water utilization and recycling. J Inland Fish Soc India 30: 9-18.

20. Ghosh A, Rao LH, Banerjee SC (1974) Studies of hydrobiological conditions of a sewage fed pond with a note on their role in fish culture. J Inland Fish Soc India 6: 51-61.

21. Rai SP (1994) Impact of sewage effluent on soil variable of some non drainable fish pond. J Inland Fish Soc India 26: 83-88.

22. Chakraborty NM, Asthana A (1989) Plankton succession and ecology of a sewage fed fish pond in West Bengal. Envt Ecol 7: 549-554.

23. Hepher B, Schroeder GL (1977) Wastewater utilization in Israel aquaculture

24. Allen GH, Hepher B (1979) Recycling of Waste through aquaculture and constraints to wider application.

25. Bhowmik ML, Sarkar UK, Pandey BK (1993) Plankton abundance and composition in sewage-fed fish ponds. J Inland Fish Soc India 25: 23-29.

26. Saha KC (1970) Sewage-fed Fisheries. In Fisheries of West Bengal. West Bengal Government Press, West Bengal.

27. Bilgrami KS, Duttamunshi JS, Bhowmik BN (1985) Biomonitoring of river Ganges at polluted sites in Bihar.

28. Schaeperclause W (1959) Die Karpfenteich wirtschft in der Denfschen Demokratischen republic, Stizungsher Dtsch Akal. 